\title{
Mechanisms of Amyloid-Beta Peptide Uptake by Neurons: The Role of Lipid Rafts and Lipid Raft-Associated Proteins
}

\author{
Aaron Y. Lai ${ }^{1}$ and JoAnne McLaurin ${ }^{1,2}$ \\ ${ }^{1}$ Tanz Centre for Research in Neurodegenerative Diseases, University of Toronto, 6 Queen's Park Crescent West, \\ Toronto, ON, Canada M5S $3 \mathrm{H} 2$ \\ ${ }^{2}$ Department of Laboratory Medicine and Pathobiology, University of Toronto, Toronto, ON, Canada M5S $3 \mathrm{H} 2$
}

Correspondence should be addressed to JoAnne McLaurin, j.mclaurin@utoronto.ca

Received 15 October 2010; Accepted 29 November 2010

Academic Editor: Anne Eckert

Copyright (C) 2011 A. Y. Lai and J. McLaurin. This is an open access article distributed under the Creative Commons Attribution License, which permits unrestricted use, distribution, and reproduction in any medium, provided the original work is properly cited.

\begin{abstract}
A hallmark pathological feature of Alzheimer's disease (AD) is the accumulation of extracellular plaques composed of the amyloidbeta $(\mathrm{A} \beta)$ peptide. Thus, classically experiments were designed to examine $\mathrm{A} \beta$ toxicities within the central nervous system (CNS) from the extracellular space. However, a significant amount of evidence now suggests that intraneuronal accumulation of $A \beta$ is neurotoxic and may play an important role in the disease progression of AD. One of the means by which neurons accumulate intracellular $\mathrm{A} \beta$ is through uptake of extracellular $\mathrm{A} \beta$ peptides, and this process may be a potential link between $\mathrm{A} \beta$ generation, synaptic dysfunction, and $\mathrm{AD}$ pathology. Recent studies have found that neuronal internalization of $\mathrm{A} \beta$ involves lipid rafts and various lipid raft-associated receptor proteins. Uptake mechanisms independent of lipid rafts have also been implicated. The aim of this paper is to summarize these findings and discuss their significance in the pathogenesis of AD.
\end{abstract}

\section{Introduction}

Alzheimer's disease (AD) is the most common form of dementia with a high prevalence rate among the aging population [1]. The clinical symptoms are characterized by loss of selective cognitive functions, particularly memory loss [1]. These traits are accompanied by neuropathological features observed in postmortem AD brains, including loss of neurons and synapses in cortical and subcortical regions, as well as extracellular plaques composed of aggregated amyloid-beta $(\mathrm{A} \beta)$ peptides and intracellular neurofibrillary tangles that contain hyperphosphorylated Tau protein [2]. Although the precise role of $\mathrm{A} \beta$ in $\mathrm{AD}$ etiology remains inconclusive, the current consensus is that it is a central player in the development of the disease. This hypothesis is supported by a variety of transgenic mouse lines that contain mutations in the $A \beta$ processing machinery [3]. These mice display some of the neuropathologies and behavioral deficits similar to that observed in AD patients, providing a link between abnormal $\mathrm{A} \beta$ production and disease development [3]. Nevertheless, the cellular events that occur between production of the $\mathrm{A} \beta$ peptide and degeneration of a neuron remain inconclusive. $A \beta$ is produced from its membrane-embedded precursor, amyloid precursor protein (APP), through sequential cleavage by enzyme complexes $\beta$ - and $\gamma$-secretases [4]. Two distinct cleavage pathways exist. In the nonamyloidogenic pathway, APP is cleaved by $\alpha$-secretase resulting in an 83 -amino-acid C-terminal fragment that is further cleaved by the $\gamma$-secretase into a short p3 peptide [5]. In the amyloidogenic pathway, the cleavage occurs at 99 rather than 83 amino acids from the C-terminus and is mediated by the $\beta$-secretase [6]. This results in a 99-amino-acid peptide that contains an intact hydrophobic region termed the $\mathrm{A} \beta$ region [6]. Subsequent cleavage by $\gamma$-secretase releases this peptide region forming the $\mathrm{A} \beta$ peptide normally 40 -amino-acids in length $(\mathrm{A} \beta 40)$ [6]. An alternate cleavage by the $\gamma$-secretase results in a less abundant form of the peptide 42 residues in length (A $\beta 42)$ [7]. A $\beta 42$ is more hydrophobic and has a greater tendency to aggregate into fibrils and plaques compared to $\mathrm{A} \beta 40$ [7]. $\mathrm{A} \beta 42$ is also the prevalent isoform found in the amyloid plaques of AD patients [8]. Several hypotheses 
have been proposed in regards to how $\mathrm{A} \beta$ production leads to neuronal degeneration and toxicity: $A \beta$ monomers are known to aggregate into higher-molecular weight oligomers and fibrils [9]. The hydrophobicity of $A \beta$ allows it to target neurons directly; extracellular $A \beta$ aggregates can interact with neuronal membranes resulting in disruptions in bilayer permeability [10]. $\mathrm{A} \beta$ oligomers and fibrils also bind to several membrane proteins which may induce change or loss of protein function [11].

\section{Sources of Intracellular $\mathbf{A} \beta$}

Despite evidence suggesting that $A \beta$ exerts its effects extracellularly, reports have shown that $\mathrm{A} \beta$ in the intraneuronal compartment may play an important role. As early as the $1980 \mathrm{~s}$, researchers have observed that in $\mathrm{AD}$ patients, $\mathrm{A} \beta$ deposition inside the cells precedes its accumulation in the extracellular space $[12,13]$. The findings in human subjects are corroborated by transgenic mouse models of $\mathrm{AD}$, where intraneuronal $\mathrm{A} \beta$ is commonly observed. Various mouse models display $\mathrm{A} \beta$ deposits inside neurons well before the appearance of extracellular plaques [14-21]. In the triple transgenic ( $3 \mathrm{xTg}) \mathrm{AD}$ mice, the level of intraneuronal $\mathrm{A} \beta$ is found to correlate with synaptic dysfunction and memory impairment $[21,22]$. In spite of these observations, the concept that intraneuronal $A \beta$ contributes to disease progression has not been ubiquitously accepted. One largescale human study found contradicting evidence, such that the level of intraneuronal $A \beta$ increases with age even in non$\mathrm{AD}$ individuals [23], suggesting that $\mathrm{A} \beta$ inside neurons may not have a pathological role. This might be explained by the fact that some fixation and staining methods detect $A \beta$ in the extracellular space more strongly than inside cells [2426]. For example, studies have shown that exposure to formic acid, which is a commonly used step in $\mathrm{A} \beta$ staining, does not yield the strongest intracellular $\mathrm{A} \beta$ signal whereas antigen retrieval by heating enhances the signal $[24,25]$. Bayer and Wirths [26] suggested that in transgenic mice studies, brains are normally fixed by cardiac perfusion in a short time frame, leading to more frequent observations of intraneuronal $A \beta$ in mouse models than in human tissues that are exposed to extended periods of postmortem fixation.

Although the role of intraneuronal $A \beta$ in disease development is controversial, there is no dispute regarding the presence of $A \beta$ within neurons. The key question that follows is the origin of the accumulated $\mathrm{A} \beta$ inside neurons. Thus far it is unclear whether the accumulation originates from direct deposition of $A \beta$ intracellularly or from uptake from the extracellular $A \beta$ pool. In addition to the plasma membrane, APP is also found on membranes of mitochondria, the transGolgi network, endoplasmic reticulum (ER), endosomes, autophagosomes, and lysosomes [27]. $\beta$ - and $\gamma$-secretases have been found in these subcellular compartments [27]; hence $\mathrm{A} \beta$ production occurs intracellularly as well. Endosomes in particular are hypothesized to be a major site of $\mathrm{A} \beta$ production due to their acidic $\mathrm{pH}$ and coexpression of both $\beta$ - and $\gamma$-secretases [27]. Studies have shown that internalization of APP from the plasma membrane to endosomes can occur via endocytosis, and that blockade of this process reduces intracellular $A \beta$ levels [28]. Coexpression of $\beta$ - and $\gamma$-secretases is also found in the Golgi [27], suggesting that the secretory pathways are also potential sites of $A \beta$ production. Intracellular trafficking of APP may act as a cellular mechanism that regulates the production of $A \beta$ since some cellular compartments have optimal conditions for APP cleavage while others do not. Nonetheless, there is no question that a significant amount of APP is cleaved at the plasma membrane resulting in extracellular deposition of $A \beta$. One possible fate of deposited $A \beta$ is re-entry into cells. Glial cells including astrocytes and microglia are the putative phagocytic cells in the CNS. Extracellular $A \beta$ can be internalized by glial cells via phagocytosis as well as pinocytosis and endocytosis [29-31]. A significant portion of deposited $A \beta$ is likely taken up by glia. Neurons, on the other hand, are not generally considered phagocytic cells. Nonetheless, reports have shown that $\mathrm{A} \beta$ uptake can occur in neurons contributing to the accumulation of intraneuronal $\mathrm{A} \beta[6,26]$. Due to their potential significance in $\mathrm{AD}$ etiology, the cellular mechanisms that mediate neuronal $A \beta$ uptake have garnered increased attention in recent years. Current data suggest that the majority of $A \beta$ uptake mechanisms in neurons involve membrane microdomains termed lipid rafts.

\section{Lipid Metabolism, Lipid Rafts, and AD}

Lipid rafts are mobile microdomains in plasma or organelle membranes that are rich in cholesterol and sphingolipids [32]. This specialized lipid composition distinct from the surrounding membrane phospholipids allows lipid rafts to associate with select groups of proteins [32]. Lipid raftassociated proteins have key roles in protein entry and trafficking as well as signal transduction [32]. The idea that lipid rafts may be associated with $\mathrm{A} \beta$ metabolism originated from cholesterol studies [32]. In AD patients, serum cholesterol levels correlated with $A \beta$ load in the brain [33]. Individuals with high cholesterol levels during midlife are at a higher risk to develop $\mathrm{AD}$ later in life [34], whereas individuals treated with cholesterol lowering drugs have a lower prevalence of $\operatorname{AD}[35,36]$. Similar trends were observed in animal and cell culture models [32]. Notably, accumulation of intraneuronal $\mathrm{A} \beta$ was increased in transgenic $\mathrm{AD}$ mice fed with a high cholesterol diet $[37,38]$. Despite evidence supporting a role for cholesterol in $\mathrm{AD}$ pathogenesis, clinical use of cholesterol-lowering statins to treat $\mathrm{AD}$ patients has not yielded consistent results [39]. Furthermore, postmortem analyses of AD brains showed that cholesterol levels in the hippocampus and the frontal cortex were not significantly different from that of age-matched controls $[40,41]$. Although the precise role of cholesterol in $\mathrm{AD}$ is unclear, the discovery of $\beta$-secretase, $\gamma$-secretase, and APP at lipid rafts suggests that cholesterol is involved in APP processing and $\mathrm{A} \beta$ production [42-44]. Indeed, cholesterol depletion in cultured neurons decreases the production of A $\beta$ [45]. Cholesterol depletion is a commonly used method to compromise lipid raft integrity and has been shown to dissociate $\gamma$-secretase from lipid rafts $[44,46]$. Increased targeting of $\beta$-secretase to lipid rafts promoted its cleavage activity of APP [47]. Studies have also found that unlike 
APP cleavage, which occurs mostly at lipid rafts, non-APP substrates of the $\gamma$-secretase were cleaved at non-lipid raft domains [44]. Lipid rafts may thus serve as a platform for secretases to differentiate APP processing from other secretase-dependent cellular processes.

\section{A $\beta$ Binding, Aggregation, and Internalization at Lipid Rafts}

In addition to processing of APP, lipid rafts have been proposed as a site for binding of extracellular $A \beta$ and a niche for $A \beta$ aggregation $[11,48]$. Exogenously applied oligomeric $\mathrm{A} \beta$ has been shown to concentrate at lipid rafts of cultured neurons [49]. Lipid rafts isolated from $\mathrm{AD}$ mice are also concentrated with soluble nonfibrillar $A \beta[50]$. Sphingolipid derivatives such as sphingomyelin and gangliosides can readily bind both soluble and fibrillar $A \beta$ and are thought to be the major $\mathrm{A} \beta$-recruiting component in lipid rafts [51-54]. Cholesterol has also been shown to interact with soluble and fibrillar $A \beta$ [55]. Gangliosides, in particular monosialotetrahexosylganglioside (GM1), is known to form an "A $\beta$-seed" by complexing with soluble $A \beta[51,52]$. GM1-bound $\mathrm{A} \beta(\mathrm{GM} 1 / \mathrm{A} \beta)$ has a different conformation than that of soluble $A \beta$ and seeds the formation of $A \beta$ aggregates $[51,52]$. Binding of $\mathrm{A} \beta$ to lipid rafts has been shown to promote its oligomerization and subsequently fibril formation, possibly via the seeding and aggregationpromoting effect of GM1/A $\beta[56,57]$. Disruption of lipid rafts in cultured pheochromocytoma cells was able to protect them against toxicity induced by $\mathrm{A} \beta$ oligomers $[58,59]$. The interaction of $\mathrm{A} \beta$ with lipid rafts may induce toxicity via several mechanisms: $A \beta$ aggregation at lipid rafts can induce membrane perturbations by oxidative damage $[60$, 61]. Alternatively, interaction of $A \beta$ oligomers with GM1 decreases membrane fluidity and in turn stimulates APP processing, resulting in a vicious cycle of $A \beta$ overproduction [62]. It has also been suggested that rather than aggregating on the cell surface, a portion of the $\mathrm{A} \beta$ binding to lipid rafts is internalized [63]. One of the earlier studies examining $\mathrm{A} \beta$ internalization observed that in human fibroblast cells, $\mathrm{A} \beta$ accumulated intracellularly were in a high-molecular weight oligomeric state [64]. A later study using human neuroblastoma cells showed that not all of the applied exogenous $A \beta$ oligomers were internalized; the oligomers bound to the membrane formed aggregates larger than the internalized oligomers [63]. These findings suggest that $A \beta$ uptake may precede its aggregation at the membrane, and that surface aggregation of $\mathrm{A} \beta$ takes place as a result of saturation of the uptake pathway. The authors also demonstrated that oligomeric $\mathrm{A} \beta$ was internalized more efficiently than fibrillar $A \beta$ [63]. Saavedra et al. [65] in a study using cervical sympathetic neurons found that internalized $A \beta$ oligomers colocalized with cholera toxin subunit $\mathrm{B}(\mathrm{CTxB})$, a lipid raft marker that specifically binds to GM1, suggesting that $\mathrm{A} \beta$ internalization occurs at lipid rafts, possibly via GM1 binding. The authors further showed that reduction of cellular cholesterol and sphingolipid levels significantly decreased $A \beta$ uptake [65]. A recent study by Singh et al. [66] using mouse neuroblastomas also found colocalization of internalized $\mathrm{A} \beta$ with $\mathrm{CTx} B$. The authors pharmacologically inhibited lipid raft-dependent endocytosis which resulted in decreased uptake of soluble $A \beta$ [66]. Thus far it is unclear whether the lipid components or the associated receptor proteins are responsible for initiating $\mathrm{A} \beta$ uptake at lipid rafts. $A \beta$, in addition to lipids, can bind to a wide range of membrane proteins [11], which may act as carriers of $\mathrm{A} \beta$ upon endocytosis of the $\mathrm{A} \beta$-receptor protein complex. The following section discusses the various routes of cellular entry for extracellular $\mathrm{A} \beta$.

\section{Mechanisms of $\mathbf{A} \boldsymbol{\beta}$ Uptake}

5.1. Glutamate Receptors. One of the earliest pathological features in $\mathrm{AD}$ that coincides with accumulation of intraneuronal $A \beta$ is synaptic aberrations including changes in the shape and the protein composition of synapses as well as an overall decrease in abundance. Application of exogenous soluble $\mathrm{A} \beta$ to hippocampal slices leads to $\mathrm{A} \beta$ accumulation in CA1 neurons coupled with decreased expression of the synaptic marker synaptophysin [67]. Extracellular A $\beta$ may thus preferentially target synapses. There is a wide range of lipid raft-associated receptors localized at the synaptic membrane. One receptor that is highly expressed at synapses is the $\mathrm{N}$-methyl-D-aspartic acid (NMDA) receptor for the neurotransmitter glutamate. NMDA receptors are associated with lipid rafts $[68,69]$. Exposure of the NMDA receptor to $A \beta$ oligomers is known to promote endocytosis of the receptor as well as other signaling events associated with NMDA receptor trafficking [28]. In hippocampal slices treated with soluble $\mathrm{A} \beta$, cotreatment with an NMDA receptor antagonist prevented the neuronal accumulation of $A \beta$, suggesting that activation of the receptor by $A \beta$ may trigger endocytosis of the $\mathrm{A} \beta$-NMDA receptor complex [70]. However, whether $A \beta$ actually binds to NMDA receptor is unclear. In a study examining the effects of $A \beta$ oligomers on primary hippocampal neurons, Lacor et al. [71] noted that the binding sites of $A \beta$ oligomers overlap with immunoreactivity of NMDA receptor 1 (NR1), a subunit of the NMDA receptor, and postsynaptic density-95 (PSD-95), an anchoring protein associated with the NMDA receptor. This would suggest physical associations between $\mathrm{A} \beta$ and the NMDA receptor. However, colocalization and coprecipitation of the two in an intracellular compartment have not been demonstrated. Some hypothesized that the NMDA receptor and its associated signaling cascades interact with $\mathrm{A} \beta$ via another $\mathrm{A} \beta$-binding receptor protein. In the study by $\mathrm{Bi}$ et al. [70], cotreatment of antagonists against integrins with soluble $A \beta$ nearly doubled the amount of internalized $\mathrm{A} \beta$ compared to $\mathrm{A} \beta$ treatment alone. As NMDA receptor antagonist yielded opposite trends, the authors hypothesize that membrane integrins and the NMDA receptor modulate $\mathrm{A} \beta$ uptake cooperatively [70]. Integrins are associated with lipid rafts as well [72]. $A \beta$ is known to bind integrins directly [73], and in addition to regulating $A \beta$ uptake, integrins also modulate the neurotoxic effects of soluble $A \beta$ [70]. There is currently no data suggesting that integrins physically interact with the NMDA receptor despite evidence showing that integrin signaling modulates NMDA receptor activity 
and trafficking [74-76]. Therefore, it is possible that both receptors act as $\mathrm{A} \beta$ carriers but at the same time induce other signaling cascades independent of the uptake process.

Another glutamate receptor modulated by integrin signaling is the $\alpha$-amino-3-hydroxyl-5-methyl-4-isoxazolepropionate (AMPA) receptor [76-78]. The AMPA and NMDA receptors are often co-expressed by the same glutamatergic synapses. Like NMDA receptors, AMPA receptors are closely associated with lipid rafts and GM1 in particular $[68,79-81]$. However, AMPA receptor recycling to and from the synaptic surface is fast compared to that of NMDA receptors, suggesting that AMPA receptors may act as a more efficient carrier of $\mathrm{A} \beta$ than NMDA receptors [82]. In a study using primary hippocampal neurons, Zhao et al. [82] showed that AMPA receptor trafficking is regulated by $\mathrm{A} \beta$ oligomers. Antagonists against the AMPA receptor inhibited $\mathrm{A} \beta$ internalization as in the case with NMDA receptor antagonists [82]. The authors further demonstrated that the glutamate receptor 2/3 (GluR2/3) subunit of AMPA receptors co-immunoprecipitated with $A \beta$ oligomers [82], implicating a role for AMPA receptors as an $\mathrm{A} \beta$ carrier. Several other research groups have also reported endocytosis of AMPA receptors induced by $\mathrm{A} \beta$ oligomers $[83,84]$, leading to the speculation that endogenous $\mathrm{A} \beta$ at physiological levels may have essential roles in the maintenance of synapses. A recent study demonstrated that in mice overexpressing APP, the density of dendritic spines is increased at a young age before accumulation of $A \beta$ nullifies the effect at an older age [85]. Hence it is possible that APP at synaptic membranes promotes surface expression and stabilization of glutamate receptors, while cleavage of APP and synaptic release of $\mathrm{A} \beta$ would promote opposite effects. The uptake of $A \beta$ by glutamate receptors may serve as a regulatory mechanism that prevents $\mathrm{A} \beta$-induced synaptic depression.

5.2. Acetylcholine Receptors. Another neurotransmitter receptor implicated in the uptake of $\mathrm{A} \beta$ is the $\alpha 7$ nicotinic cholinergic receptor $(\alpha 7 \mathrm{nChR})$ for the neurotransmitter acetylcholine. The role of acetylcholine and its receptors have received continuous attention in the $\mathrm{AD}$ field due to the high susceptibility of cholinergic neurons to degenerate in $\mathrm{AD}$ pathology [86]. Several hypotheses have been formed to explain this regional transmitter-specific vulnerability. It has been proposed that cholinergic signaling modulates APP processing [86]. Conversely, $A \beta$ can affect acetylcholine release from the presynaptic terminal as well as signaling of nicotinic receptors in the postsynaptic compartment [86]. The $\alpha 7 \mathrm{nChR}$ in particular is known to bind soluble $\mathrm{A} \beta$ with high affinity $[87,88]$, leading to the speculation that $\mathrm{A} \beta$ may be internalized via complex formation with the $\alpha 7 \mathrm{nChR}$. Nagele et al. [89] investigated this possibility in a study examining both human $\mathrm{AD}$ tissues and human neuroblastoma cells. The authors found that immunoreactivity of $\alpha 7 \mathrm{nChR}$ and $\mathrm{A} \beta$ is highly colocalized in neurons of the hippocampus, entorhinal cortex, and cerebellum [89]. They observed similar findings in vitro; in neuroblastoma cells transfected with $\alpha 7 \mathrm{nChR}$, soluble $\mathrm{A} \beta$ treatment induced large punctate staining of $\alpha 7 \mathrm{nChR}$ which colocalized with $\mathrm{A} \beta$ immunoreactivity [89]. Untransfected cells exhibited slower internalization of $\mathrm{A} \beta$ and lower susceptibility to $A \beta$-induced toxicity, suggesting a role for $\alpha 7 \mathrm{nChR}$ as an $\mathrm{A} \beta$ carrier [89]. Although subcellular colocalization of $\mathrm{A} \beta$ and $\alpha 7 \mathrm{nChR}$ has not been reported, circumstantial evidence indicates that neurotoxic effects of intracellular $\mathrm{A} \beta$ are mediated at least partly by uptake via $\alpha 7 \mathrm{nChR}$ independent of its agonist effects. For instance, binding of $\alpha 7 \mathrm{nChR}$ by $\mathrm{A} \beta$ results in primarily neurotoxic effects, yet paradoxically, binding of the same receptor by other competing agonists promotes neuroprotection [90]. Another study showed similar paradoxical results where disruption of lipid rafts attenuated $\mathrm{A} \beta$-mediated $\alpha 7 \mathrm{nChR}$ signaling but not nicotine-mediated signaling [91]. An explanation for this paradox is that the toxic effects of $\mathrm{A} \beta$ on cholinergic synapses occur after internalization by cholinergic receptors, and that activation of the receptor upon $\mathrm{A} \beta$ binding at common agonist sites triggers other independent pathways. This explanation may also justify contradictory findings in animal studies, where transgenic $\mathrm{AD}$ mice deficient in $\alpha 7 \mathrm{nChR}$ expression exhibited exacerbated $\mathrm{AD}$ pathology in one report [92] and ameliorated pathology in another [93].

5.3. Apolipoproteins. A group of proteins implicated in the trafficking of $\mathrm{A} \beta$ that are not localized to synaptic membranes are apolipoproteins. As implied by the nomenclature, the amphipathic nature of apolipoproteins enables them to bind and transport lipids within a water-soluble milieu. Some apolipoproteins act as soluble chaperones for hydrophobic peptides such as $A \beta$ [94]. In nonfamilial $A D$, the $\varepsilon 4$ allele of the gene encoding apolipoprotein $\mathrm{E}$ (apoE) is the most prevalent genetic risk factor [94]. Consequently, the potential link between apoE function and $A \beta$ toxicity has been studied extensively. Transgenic AD mice deficient in apoE display reduced $A \beta$ load, suggesting a role for apoE in promoting $A \beta$ accumulation [95]. Isoform-specific properties of the apoE4 allele were also investigated: binding studies comparing different apoE isoforms showed that apoE2 and apoE3 bind soluble $A \beta$ more efficiently than apoE4 that preferentially binds to an intermediate aggregate form of $A \beta$ $[96,97]$. An in vitro study on purified synaptosomes showed that soluble $\mathrm{A} \beta$, but not fibrillar $\mathrm{A} \beta$, complexes with apoE, and that formation of the apoE- $\mathrm{A} \beta$ complex is crucial in the capacity of apoE3 to promote $A \beta$ internalization [98]. The authors observed the same trend in intact neurons of the dorsal root ganglia [98]. The capacity of apoE to promote uptake of soluble $A \beta$ is isoform-dependent; in the case of apoE4, promotion of uptake requires proteolytic cleavage [99]. In tissues of $\mathrm{AD}$ patients, immunoreactivity of apoE strongly correlates with that of intracellular $A \beta$, suggesting that apoE is internalized with $A \beta[100]$. Whether $\mathrm{A} \beta$ enters neurons as a complex with apoE or as a chaperonefree entity is unclear. The receptor that mediates apoEdependent internalization of $A \beta$ is also undefined. Similar to $\mathrm{A} \beta$, apoE does not appear to have a dedicated receptor but is known to bind several putative receptor proteins. In transgenic $\mathrm{AD}$ mice, apoE is found to accumulate in lipid rafts suggesting that the apoE- $\mathrm{A} \beta$ complex may target raft-associated receptor proteins [50]. Moreover, apoE has 
been observed to target neurotransmitter receptors such as $\alpha 7 \mathrm{nChR}$ [90], leading to the hypothesis that uptake of $\mathrm{A} \beta$ by neurotransmitter receptors results from apoE-receptor binding rather than direct interaction between $A \beta$ and the receptor. The surface receptors most often associated with apoE are the low-density lipoprotein receptor-related proteins (LRPs), a family of multiligand receptors known to have a high endocytosis rate [101]. LRP1 in particular has several known roles in AD. For instance, LRP1 binds to APP at the cell surface and subsequent endocytosis targets APP to the lysosome, modulating A $\beta$ production [101]. The same endocytic mechanism is thought to mediate the uptake of A $\beta$. Gylys et al. [98] showed that addition of receptorassociated protein (RAP), an antagonist of LRP1, along with the apoE- $A \beta$ complex significantly reduced internalization of soluble $\mathrm{A} \beta$. A recent study in neuroblastoma and neuronal cell lines observed similar trends, such that RNA interference of LRP1 inhibited and overexpression of LRP1 stimulated soluble $A \beta$ uptake [102]. In vivo experiments found that AD mice overexpressing LRP had increased intraneuronal accumulation of $A \beta$ [103]. It has been suggested that LRP1 may bind soluble $\mathrm{A} \beta$ directly without chaperones. Binding assays, however, showed otherwise [104], and in an apoEfree environment, LRP inhibition did not alter $A \beta$ uptake [65], suggesting that formation of the apoE- $\mathrm{A} \beta$ complex is required for internalization by LRP1. Notably, LRP1 associates with lipid rafts transiently such that it traffics between raft and nonraft membrane domains [105]. The motility of LRP1 may serve as a mechanism to regulate its availability to $\mathrm{A} \beta$. The LRP antagonist receptor-associated protein (RAP), in addition to its LRP-modulating activities, has molecular properties similar to chaperone proteins like apoE. Kanekiyo and $\mathrm{Bu}$ [106] showed that RAP forms complexes with soluble $\mathrm{A} \beta$ much like apoE and similarly promotes $\mathrm{A} \beta$ uptake into neuroblastoma cells. They further demonstrated that uptake of soluble $\mathrm{A} \beta$ with RAP is independent of LRP1 [106], which is somewhat surprising as RAP is routinely used experimentally to inhibit LRP1 activity. The precise route of entry for RAP-A $\beta$ complexes is thus unclear.

5.4. Other A $\beta$-Binding Proteins. The proteins implicated in $\mathrm{A} \beta$ uptake represent only a small percentage of soluble and membrane proteins that physically interact with $A \beta$. The list of $\mathrm{A} \beta$-binding proteins is extensive (see [11] for a review). One notable receptor protein implicated in neuronal internalization of $A \beta$ is the receptor for advanced glycation end products (RAGE). RAGE is a member of the immunoglobulin superfamily that interacts with several classes of ligands [107]. Complex formation between RAGE and soluble $A \beta$ has been demonstrated [108]. Neuronal overexpression of RAGE in transgenic AD mice results in exacerbated AD pathology [109], suggesting that RAGE may promote intracellular $A \beta$ accumulation. To demonstrate the role of RAGE in A $\beta$ uptake, Takuma et al. [107] derived primary cortical neurons from RAGE-deficient mice, showing that neurons without RAGE expression internalized markedly less soluble $A \beta$ compared to wild-type neurons. Interestingly, while internalization facilitated by most receptors appeared to localize to lysosomes, the authors showed by electron microscopy that $\mathrm{A} \beta$ internalized by RAGE accumulates in the mitochondria [107]. Accumulation of $\mathrm{A} \beta$ in the mitochondria is a well-documented occurrence (reviewed in [110]). Mitochondria are closely associated with the ER [111], hence it is possible that $\mathrm{A} \beta$ in the mitochondria originates from endosome-Golgi and Golgi-ER vesicular transport. However, since mitochondria are not classically associated with the endosomal pathways, it is proposed that mitochondrial $A \beta$ derives from transport of cytosolic $A \beta$. Although mitochondria have been shown to import cytosolic $A \beta$ via translocases [112], it is unclear how extracellular $A \beta$, which enters the cell by endocytosis of RAGE, translocates out of the endo-lysosomal compartments into the cytosol. Localization of internalized $\mathrm{A} \beta$ to the mitochondria may not be specific to RAGE endocytosis; therefore, future studies need to determine whether $A \beta$ endocytosed through other receptor proteins also localize to mitochondria.

The serpin-enzyme complex receptor (SEC-R) is another less documented protein implicated in the uptake of $A \beta$ [113]. It was originally identified in leukocytes as a receptor for antiprotease enzymes. Although SEC-R is also expressed in neurons [113], its role in neuronal cells and $A \beta$-associated processes is unknown. Boland et al. [113] showed that SEC$\mathrm{R}$ binds to soluble $\mathrm{A} \beta$ and promotes uptake in pheochromocytoma cells. Whether SEC-R functions similarly in neurons has not been determined. A recent study reported that multiple epidermal growth factor-like domains 10 (MEGF10), a newly identified receptor involved in clearance of cell corpses, also modulates soluble $\mathrm{A} \beta$ uptake [66]. Although the authors show expression of MEGF10 in neurons of the hippocampus, it is unclear whether MEGF10 physically interacts with $A \beta$, and henceforth whether MEGF10 mediates $A \beta$ uptake or merely modulates the process.

5.5. Endocytic Pathways of $A \beta$. A topic that has generated a significant amount of interest concerns the specific endocytic pathways involved in $\mathrm{A} \beta$ uptake. Endocytosis is a wellstudied phenomenon in cell biology and to date several distinct pathways involving different protein machinery have been identified (for a review see [114]). The classical endocytic pathway involves invagination of the plasma membrane at the site of the receptor-cargo binding; the invaginated vesicle is then coated with adaptor proteins, which recruit guanosine triphosphatases (GTPases) that provide the necessary energy to facilitate cleavage of the vesicle from the cell membrane and delivery to endosomes or other subcellular compartments [114]. By far the most frequently reported process is dependent on clathrin and dynamins [114]. Clathrin is an adaptor protein that forms the primary component of the vesicle coating complex [114]. Dynamins are responsible for the membrane cleavage to release the invaginated vesicle from the plasma membrane [114]. Endocytosis at lipid rafts, however, is thought to proceed in a clathrin-independent manner (reviewed in [115]). Invaginations formed from lipid rafts, termed caveolae, are rich in cholesterol and sphingolipids and are morphologically distinct from clathrin-coated invaginations [115]. Caveolins are the major protein component of caveolae and are thought to cooperatively regulate lipid raft endocytosis with 
TABLE 1: Summary of receptor proteins involved in the neuronal uptake of A $\beta$.

\begin{tabular}{|c|c|c|c|c|c|}
\hline \multicolumn{6}{|c|}{ Receptor proteins involved in neuronal $\mathrm{A} \beta$ uptake } \\
\hline & $\mathrm{A} \beta$ binding & $\mathrm{A} \beta$ species & $\begin{array}{c}\text { intracellular } \\
\text { colocalization } \\
\text { with } \mathrm{A} \beta \\
\end{array}$ & $\begin{array}{c}\text { cell type where } \\
\text { uptake was } \\
\text { observed }\end{array}$ & endocytic pathway \\
\hline \multicolumn{6}{|c|}{ Membrane receptors } \\
\hline NMDA receptor & probable & $\begin{array}{c}\text { nonaggregated, } \\
\text { oligomeric }\end{array}$ & no data & hippocampal slices & clathrin-dependent \\
\hline AMPA receptor & yes & Oligomeric & yes & $\begin{array}{l}\text { hippocampal } \\
\text { neurons }\end{array}$ & clathrin-dependent \\
\hline integrins & yes & non-aggregated & no data & hippocampal slices & clathrin-dependent \\
\hline$\alpha 7 \mathrm{nChR}$ & yes & non-aggregated & no data & neuroblastomas & $\begin{array}{l}\text { both clathrin-dependent } \\
\text { and independent }\end{array}$ \\
\hline LRP1 & via apoE & non-aggregated & no data & $\begin{array}{l}\text { DRG neurons, } \\
\text { neuroblastomas }\end{array}$ & clathrin-dependent \\
\hline RAGE & yes & non-aggregated & no data & cortical neurons & no data \\
\hline MEGF10 & no data & non-aggregated & no data & neuroblastomas & $\begin{array}{c}\text { raft-dependent/ } \\
\text { caveolin-independent }\end{array}$ \\
\hline \multicolumn{6}{|l|}{ Soluble receptors } \\
\hline apoE & yes & non-aggregated & yes & $\begin{array}{l}\text { DRG neurons, } \\
\text { neuroblastomas }\end{array}$ & $\begin{array}{c}\text { clathrin-dependent, via } \\
\text { LRP1 }\end{array}$ \\
\hline RAP & yes & non-aggregated & no data & neuroblastomas & no data \\
\hline
\end{tabular}

cholesterol and gangliosides [115]. It was originally thought that endocytosis at lipid rafts are caveolin- and dynamindependent. However, there is increasing evidence suggesting a caveolin-independent dynamin-dependent pathway as well as a flotillin-dependent dynamin-independent pathway [114]. The notion that lipid raft endocytosis does not involve clathrin has also been challenged as studies have observed clathrin-dependent endocytosis of lipid raft-associated proteins $[116,117]$.

Among receptor proteins that mediate $\mathrm{A} \beta$ uptake, LRP1 has been shown to endocytose $A \beta$ via a clathrin-dependent process; neuroblastoma and neuronal cell lines deficient in clathrin internalized significantly less soluble $\mathrm{A} \beta$ as well as LRP1 [102]. Requirement for clathrin has also been shown in endocytosis of the NMDA and AMPA receptors for glutamate [118]. Not all routes of $\mathrm{A} \beta$ uptake, however, are clathrindependent. In the case of $\alpha 7 \mathrm{nChR}$, in Chinese hamster ovary cells transfected with $\alpha 7 \mathrm{nChR}$, endocytosis of the receptor occurs in the absence of clathrin, and in fact, dynamins as well [119]. This contradicts an earlier study in $\alpha 7 \mathrm{nChR}-$ transfected human neuroblastomas that reported inhibition of $\alpha 7 \mathrm{nChR}$ endocytosis along with decreased soluble $\mathrm{A} \beta$ internalization by treatment with phenylarsine oxide, an inhibitor of clathrin-coat formation [89]. It is possible that both pathways mediate $\alpha 7 \mathrm{nChR}$ endocytosis and that the specific cell type can determine which pathway is dominant. Clathrin-independent internalization of $\mathrm{A} \beta$ has been reported in several different neuronal cell types. In mouse neuroblastoma cells, neither knockdown of clathrin nor inhibition of AP180, a clathrin-associated assembly protein, had an effect on internalization of oligomeric $A \beta$ [120]. The authors reported that inhibition of dynamin and RhoA, a small GTPase, decreased the uptake of $A \beta$ oligomers into the cell [120]. These data suggest that $\mathrm{A} \beta$ can be internalized through an IL- 2 receptor- $\beta$-like endocytic pathway dependent on lipid rafts, dynamins, and RhoA [115]. In cervical sympathetic neurons, Saavedra et al. [65] also reported that uptake of $\mathrm{A} \beta$ oligomers is independent of clathrin. A role for dynamins is again implicated, as expression of dominant negative dynamin mutant decreased $\mathrm{A} \beta$ internalization [65]. The authors further demonstrate that the internalized $\mathrm{A} \beta$ oligomers colocalized with lipid rafts, but not caveolins [65]. This dynamin-/raft-dependent caveolin-independent pathway has also been demonstrated in MEGF10-mediated uptake of soluble $\mathrm{A} \beta$ [66] and is likely similar to the IL-2 receptor-like pathway [120]. Collectively these data show that in the absence of clathrin-associated receptors, neurons endocytose $\mathrm{A} \beta$ predominantly at lipid rafts via caveolinindependent mechanisms. Clathrin-dependent endocytosis of $\mathrm{A} \beta$ can occur, but it is uncertain whether it takes place at lipid rafts. Notably, internalization of $A \beta$ oligomers in cervical sympathetic neurons preferentially occur in axons [65] while in primary hippocampal neurons and neuronlike cell lines described in other reports, the uptake appears to occur in dendritic synapses and cell bodies. These results suggest that endocytic mechanisms are varied not only in different types of neurons, but in different parts of the neuron.

Aside from endocytosis, an unconventional route of $\mathrm{A} \beta$ uptake was proposed by Kandimalla and colleagues [121]. By comparing $\mathrm{A} \beta$ uptake between primary hippocampal neurons and endothelial cells, the authors reported that while the latter requires endocytosis to internalize soluble $\mathrm{A} \beta$, neurons can take up soluble $A \beta$ by passive diffusion [121]. Neuronal uptake of soluble $\mathrm{A} \beta$ was unaffected by low temperature or low glucose, suggesting that neuronal internalization of $A \beta$ 
is not mediated by energy-dependent processes including endocytosis [121]. There are biophysical data supporting this conclusion, such that both $\mathrm{A} \beta 40$ and $\mathrm{A} \beta 42$ intercalate into phospholipid bilayers [122]. It is not unreasonable to propose that endocytosis and passive diffusion of $A \beta$ can coexist in the same neuron. Further investigation is needed to reconcile the seemingly contradicting results in regards to studies showing endocytosis-dependent $\mathrm{A} \beta$ uptake.

\section{Future Directions and Conclusions}

With the recent wealth of novel findings, our understanding of neuronal $\mathrm{A} \beta$ uptake has improved since the original discovery of intraneuronal $\mathrm{A} \beta$ in $\mathrm{AD}$ brains. Cumulatively, the current data implicate several distinct pathways of entry for extracellular $\mathrm{A} \beta$ (Table 1). Lipid raft-dependent endocytosis is the predominant $\mathrm{A} \beta$ uptake mechanism although lipid raft-independent endocytosis and nonendocytic pathways also exist. Lipid components such as cholesterol and sphingolipids have a role in modulating $\mathrm{A} \beta$ endocytosis as well as recruiting $\mathrm{A} \beta$ to the lipid raft. Questions remain as to whether lipids can act as carriers of $A \beta$ uptake independent of lipoprotein chaperones and receptor proteins. It may be the case that lipid components and raft-associated receptors synergistically carry $A \beta$ into the cell. Further investigations are needed to address these speculations. There is also little data on the long-term effects of internalized $A \beta$, which is found not only in endocytic pathways but also in other compartments including the cytosol. In vitro studies in general found that internalized $\mathrm{A} \beta$ cause lysosomal leakage and neurotoxicity, but whether the same occurs in vivo in the presence of physiological buffers is yet to be determined. In fact, most of the mechanisms of $A \beta$ uptake have not been investigated in animal models. The wealth of culture studies has nonetheless demonstrated the potential importance of $\mathrm{A} \beta$ uptake mechanisms in the pathogenesis of $\mathrm{AD}$.

\section{Acknowledgments}

The authors acknowledge support from CIHR (J. McLaurin), NSERC (J. McLaurin), Ontario Alzheimer's Society (J. McLaurin), and Ontario Postdoctoral Fellowship (A. Y. Lai).

\section{References}

[1] M. Citron, "Alzheimer's disease: strategies for disease modification," Nature Reviews Drug Discovery, vol. 9, no. 5, pp. 387-398, 2010.

[2] G. L. Wenk, "Neuropathologic changes in Alzheimer's disease," Journal of Clinical Psychiatry, vol. 64, no. 9, pp. 7-10, 2003.

[3] G. A. Elder, M. A. Gama Sosa, and R. De Gasperi, “Transgenic mouse models of Alzheimer's disease," Mount Sinai Journal of Medicine, vol. 77, no. 1, pp. 69-81, 2010.

[4] G. Thinakaran and E. H. Koo, "Amyloid precursor protein trafficking, processing, and function," Journal of Biological Chemistry, vol. 283, no. 44, pp. 29615-29619, 2008.

[5] C. Haass, A. Y. Hung, M. G. Schlossmacher, D. B. Teplow, and D. J. Selkoe, " $\beta$-amyloid peptide and a $3-\mathrm{kDa}$ fragment are derived by distinct cellular mechanisms," Journal of Biological Chemistry, vol. 268, no. 5, pp. 3021-3024, 1993.

[6] F. M. LaFerla, K. N. Green, and S. Oddo, "Intracellular amyloid- $\beta$ in Alzheimer's disease," Nature Reviews Neuroscience, vol. 8, no. 7, pp. 499-509, 2007.

[7] J. T. Jarrett, E. P. Berger, and P. T. Lansbury, "The carboxy terminus of the $\beta$ amyloid protein is critical for the seeding of amyloid formation: implications for the pathogenesis of Alzheimer's disease," Biochemistry, vol. 32, no. 18, pp. 46934697, 1993.

[8] S. G. Younkin, "The role of A $\beta 42$ in Alzheimer's disease," Journal of Physiology Paris, vol. 92, no. 3-4, pp. 289-292, 1998.

[9] L. Crews and E. Masliah, "Molecular mechanisms of neurodegeneration in Alzheimer's disease," Human Molecular Genetics, vol. 19, no. 1, pp. R12-R20, 2010.

[10] F. J. Sepulveda, J. Parodi, R. W. Peoples, C. Opazo, and L. G. Aguayo, "Synaptotoxicity of Alzheimer beta amyloid can be explained by its membrane perforating property," PLoS One, vol. 5, no. 7, Article ID e11820, 2010.

[11] Y. Verdier, M. Zarándi, and B. Penke, "Amyloid $\beta$-peptide interactions with neuronal and glial cell plasma membrane: binding sites and implications for Alzheimer's disease," Journal of Peptide Science, vol. 10, no. 5, pp. 229-248, 2004.

[12] C. L. Masters, G. Multhaup, G. Simms, J. Pottgiesser, R. N. Martins, and K. Beyreuther, "Neuronal origin of a cerebral amyloid: neurofibrillary tangles of Alzheimer's disease contain the same protein as the amyloid of plaque cores and blood vessels," EMBO Journal, vol. 4, no. 11, pp. 2757-2763, 1985.

[13] I. Grundke-Iqbal, K. Iqbal, L. George, Y. C. Tung, K. S. Kim, and H. M. Wisniewski, "Amyloid protein and neurofibrillary tangles coexist in the same neuron in Alzheimer disease," Proceedings of the National Academy of Sciences of the United States of America, vol. 86, no. 8, pp. 2853-2857, 1989.

[14] O. Wirths, G. Multhaup, C. Czech et al., "Intraneuronal $\mathrm{A} \beta$ accumulation precedes plaque formation in $\beta$-amyloid precursor protein and presenilin-1 double-transgenic mice," Neuroscience Letters, vol. 306, no. 1-2, pp. 116-120, 2001.

[15] O. Wirths, G. Multhaup, C. Czech et al., "Intraneuronal $\mathrm{APP} / \mathrm{A} \beta$ trafficking and plaque formation in $\beta$-amyloid precursor protein and presenilin-1 transgenic mice," Brain Pathology, vol. 12, no. 3, pp. 275-286, 2002.

[16] C. Casas, N. Sergeant, J. M. Itier et al., "Massive CA1/2 neuronal loss with intraneuronal and $\mathrm{N}$-terminal truncated $\mathrm{A} \beta$ accumulation in a novel Alzheimer transgenic model," American Journal of Pathology, vol. 165, no. 4, pp. 1289-1300, 2004.

[17] V. Blanchard, S. Moussaoui, C. Czech et al., "Time sequence of maturation of dystrophic neuritis associated with Abeta deposits in APP/PS1 transgenic mice," Experimental Neurology, vol. 184, no. 1, pp. 247-263, 2003.

[18] A. Lord, H. Kalimo, C. Eckman, X. Q. Zhang, L. Lannfelt, and L. N. G. Nilsson, "The Arctic Alzheimer mutation facilitates early intraneuronal $A \beta$ aggregation and senile plaque formation in transgenic mice," Neurobiology of Aging, vol. 27, no. 1, pp. 67-77, 2006.

[19] H. Oakley, S. L. Cole, S. Logan et al., "Intraneuronal $\beta$ amyloid aggregates, neurodegeneration, and neuron loss in transgenic mice with five familial Alzheimer's disease mutations: potential factors in amyloid plaque formation," Journal of Neuroscience, vol. 26, no. 40, pp. 10129-10140, 2006.

[20] M. Knobloch, U. Konietzko, D. C. Krebs, and R. M. Nitsch, "Intracellular $\mathrm{A} \beta$ and cognitive deficits precede $\beta$-amyloid 
deposition in transgenic arcA $\beta$ mice," Neurobiology of Aging, vol. 28, no. 9, pp. 1297-1306, 2007.

[21] S. Oddo, A. Caccamo, J. D. Shepherd et al., “Triple-transgenic model of Alzheimer's disease with plaques and tangles: intracellular A $\beta$ and synaptic dysfunction," Neuron, vol. 39, no. 3, pp. 409-421, 2003.

[22] L. M. Billings, S. Oddo, K. N. Green, J. L. McGaugh, and F. M. LaFerla, "Intraneuronal A $\beta$ causes the onset of early Alzheimer's disease-related cognitive deficits in transgenic mice," Neuron, vol. 45, no. 5, pp. 675-688, 2005.

[23] J. Wegiel, I. Kuchna, K. Nowicki et al., "Intraneuronal A $\beta$ immunoreactivity is not a predictor of brain amyloidosis- $\beta$ or neurofibrillary degeneration," Acta Neuropathologica, vol. 113, no. 4, pp. 389-402, 2007.

[24] M. R. D’Andrea, P. A. Reiser, D. A. Polkovitch et al., “The use of formic acid to embellish amyloid plaque detection in Alzheimer's disease tissues misguides key observations," Neuroscience Letters, vol. 342, no. 1-2, pp. 114-118, 2003.

[25] Y. Ohyagi, Y. Tsuruta, K. Motomura et al., "Intraneuronal amyloid $\beta 42$ enhanced by heating but counteracted by formic acid," Journal of Neuroscience Methods, vol. 159, no. 1, pp. 134-138, 2007.

[26] T. A. Bayer and O. Wirths, "Intracellular accumulation of amyloid-beta-a predictor for synaptic dysfunction and neuron loss in Alzheimer's disease," Frontiers in Aging Neuroscience, vol. 2, no. 8, pp. 1-10, 2010.

[27] E. H. Koo and S. L. Squazzo, "Evidence that production and release of amyloid $\beta$-protein involves the endocytic pathway," Journal of Biological Chemistry, vol. 269, no. 26, pp. 1738617389, 1994.

[28] B. L. Tang, "Neuronal protein trafficking associated with Alzheimer disease: from APP and BACE1 to glutamate receptors," Cell Adhesion and Migration, vol. 3, no. 1, pp. 118128, 2009.

[29] W. Matsunaga, T. Shirokawa, and K. Isobe, "Specific uptake of $\mathrm{A} \beta 1-40$ in rat brain occurs in astrocyte, but not in microglia," Neuroscience Letters, vol. 342, no. 1-2, pp. 129$131,2003$.

[30] S. Mandrekar, Q. Jiang, C. Y. D. Lee, J. KoenigsknechtTalboo, D. M. Holtzman, and G. E. Landreth, "Microglia mediate the clearance of soluble a $\beta$ through fluid phase macropinocytosis," Journal of Neuroscience, vol. 29, no. 13, pp. 4252-4262, 2009.

[31] S. Amor, F. Puentes, D. Baker, and P. Van Der Valk, "Inflammation in neurodegenerative diseases," Immunology, vol. 129, no. 2, pp. 154-169, 2010.

[32] K. S. Vetrivel and G. Thinakaran, "Membrane rafts in Alzheimer's disease beta-amyloid production," Biochimica et Biophysica Acta, vol. 1801, no. 8, pp. 860-867, 2010.

[33] Y. M. Kuo, M. R. Emmerling, C. L. Bisgaier et al., "Elevated low-density lipoprotein in Alzheimer's disease correlates with brain a $\beta$ 1-42 levels," Biochemical and Biophysical Research Communications, vol. 252, no. 3, pp. 711-715, 1998.

[34] M. Kivipelto, E. L. Helkala, M. P. Laakso et al., "Midlife vascular risk factors and Alzheimer's disease in later life: longitudinal, population based study," British Medical Journal, vol. 322, no. 7300, pp. 1447-1451, 2001.

[35] H. Jick, G. L. Zornberg, S. S. Jick, S. Seshadri, and D. A. Drachman, "Statins and the risk of dementia," Lancet, vol. 356, no. 9242, pp. 1627-1631, 2000.

[36] B. Wolozin, W. Kellman, P. Ruosseau, G. G. Celesia, and G. Siegel, "Decreased prevalence of Alzheimer disease associated with 3-hydroxy-3-methyglutaryl coenzyme A reductase inhibitors," Archives of Neurology, vol. 57, no. 10, pp. 14391443, 2000.

[37] L. M. Refolo, M. A. Pappolla, B. Malester et al., "Hypercholesterolemia accelerates the Alzheimer's amyloid pathology in a transgenic mouse model," Neurobiology of Disease, vol. 7, no. 4, pp. 321-331, 2000.

[38] F. S. Shie, R. C. LeBoeur, and L. W. Jin, "Early intraneuronal A $\beta$ deposition in the hippocampus of APP transgenic mice," NeuroReport, vol. 14, no. 1, pp. 123-129, 2003.

[39] B. McGuinness, J. O’Hare, D. Craig, R. Bullock, R. Malouf, and P. Passmore, "Statins for the treatment of dementia," Cochrane Database of Systematic Reviews, vol. 4, no. 8, p. CD007514, 2010.

[40] G. P. Eckert, N. J. Cairns, A. Maras, W. F. Gattaz, and W. E. Müller, "Cholesterol modulates the membrane-disordering effects of beta-amyloid peptides in the hippocampus: specific changes in Alzheimer's disease," Dementia and Geriatric Cognitive Disorders, vol. 11, no. 4, pp. 181-186, 2000.

[41] G. P. Eckert, G. P. Hooff, D. M. Strandjord et al., "Regulation of the brain isoprenoids farnesyl- and geranylgeranylpyrophosphate is altered in male Alzheimer patients," Neurobiology of Disease, vol. 35, no. 2, pp. 251-257, 2009.

[42] D. R. Riddell, G. Christie, I. Hussain, and C. Dingwall, "Compartmentalization of $\beta$-secretase (Asp2) into lowbuoyant density, noncaveolar lipid rafts," Current Biology, vol. 11, no. 16, pp. 1288-1293, 2001.

[43] K. S. Vetrivel, H. Cheng, W. Lin et al., "Association of $\gamma$-secretase with lipid rafts in post-golgi and endosome membranes," Journal of Biological Chemistry, vol. 279, no. 43, pp. 44945-44954, 2004.

[44] K. S. Vetrivel, H. Cheng, S. H. Kim et al., "Spatial segregation of $\gamma$-secretase and substrates in distinct membrane domains," Journal of Biological Chemistry, vol. 280, no. 27, pp. 2589225900, 2005.

[45] M. Simons, P. Keller, B. De Strooper, K. Beyreuther, C. G. Dotti, and K. Simons, "Cholesterol depletion inhibits the generation of $\beta$-amyloid in hippocampal neurons," Proceedings of the National Academy of Sciences of the United States of America, vol. 95, no. 11, pp. 6460-6464, 1998.

[46] S. Wahrle, P. Das, A. C. Nyborg et al., "Cholesterol-dependent $\gamma$-secretase activity in buoyant cholesterol-rich membrane microdomains," Neurobiology of Disease, vol. 9, no. 1, pp. 1123, 2002.

[47] J. M. Cordy, I. Hussain, C. Dingwall, N. M. Hooper, and A. J. Turner, "Exclusively targeting $\beta$-secretase to lipid rafts by GPI-anchor addition up-regulates $\beta$-site processing of the amyloid precursor protein," Proceedings of the National Academy of Sciences of the United States of America, vol. 100, no. 20, pp. 11735-11740, 2003.

[48] K. Matsuzaki, K. Kato, and K. Yanagisawa, "A $\beta$ polymerization through interaction with membrane gangliosides," Biochimica et Biophysica Acta, vol. 1801, no. 8, pp. 868-877, 2010.

[49] R. Williamson, A. Usardi, D. P. Hanger, and B. H. Anderton, "Membrane-bound $\beta$-amyloid oligomers are recruited into lipid rafts by a fyn-dependent mechanism," FASEB Journal, vol. 22, no. 5, pp. 1552-1559, 2008.

[50] T. Kawarabayashi, M. Shoji, L. H. Younkin et al., "Dimeric amyloid beta protein rapidly accumulates in lipid rafts followed by apolipoprotein $\mathrm{E}$ and phosphorylated tau accumulation in the Tg2576 mouse model of Alzheimer's disease," Journal of Neuroscience, vol. 24, no. 15, pp. 38013809, 2004. 
[51] A. Kakio, S. I. Nishimoto, K. Yanagisawa, Y. Kozutsumi, and K. Matsuzaki, "Interactions of amyloid $\beta$-protein with various gangliosides in raft-like membranes: importance of GM1 ganglioside-bound form as an endogenous seed for Alzheimer amyloid," Biochemistry, vol. 41, no. 23, pp. 73857390, 2002.

[52] K. Matsuzaki and C. Horikiri, "Interactions of amyloid $\beta$-peptide (1-40) with ganglioside-containing membranes," Biochemistry, vol. 38, no. 13, pp. 4137-4142, 1999.

[53] J. McLaurin and A. Chakrabartty, "Membrane disruption by Alzheimer $\beta$-amyloid peptides mediated through specific binding to either phospholipids or gangliosides. Implications for neurotoxicity," Journal of Biological Chemistry, vol. 271, no. 43, pp. 26482-26489, 1996.

[54] R. Mahfoud, N. Garmy, M. Maresca, N. Yahi, A. Puigserver, and J. Fantini, "Identification of a common sphingolipidbinding domain in Alzheimer, prion, and HIV-1 proteins," Journal of Biological Chemistry, vol. 277, no. 13, pp. 1129211296, 2002.

[55] W. G. Wood, F. Schroeder, U. Igbavboa, N. A. Avdulov, and S. V. Chochina, "Brain membrane cholesterol domains, aging and amyloid beta-peptides," Neurobiology of Aging, vol. 23, no. 5, pp. 685-694, 2002.

[56] S. I. Kim, J. S. Yi, and Y. G. Ko, "Amyloid $\beta$ oligomerization is induced by brain lipid rafts," Journal of Cellular Biochemistry, vol. 99, no. 3, pp. 878-889, 2006.

[57] T. Okada, K. Ikeda, M. Wakabayashi, M. Ogawa, and K. Matsuzaki, "Formation of toxic Abeta(1-40) fibrils on GM1 ganglioside-containing membranes mimicking lipid rafts: polymorphisms in Abeta(1-40) fibrils," Journal of Molecular Biology, vol. 382, no. 4, pp. 1066-1074, 2008.

[58] M. S. Lin, L. Y. Chen, S. S. S. Wang, Y. Chang, and W. Y. Chen, "Examining the levels of ganglioside and cholesterol in cell membrane on attenuation the cytotoxicity of beta-amyloid peptide," Colloids and Surfaces B, vol. 65, no. 2, pp. 172-177, 2008.

[59] S. S. S. Wang, D. L. Rymer, and T. A. Good, "Reduction in cholesterol and sialic acid content protects cells from the toxic effects of beta-amyloid peptides," Journal of Biological Chemistry, vol. 276, no. 45, pp. 42027-42034, 2001.

[60] M. Zampagni, E. Evangelisti, R. Cascella et al., "Lipid rafts are primary mediators of amyloid oxidative attack on plasma membrane," Journal of Molecular Medicine, vol. 88, no. 6, pp. 597-603, 2010.

[61] G. P. Eckert, W. G. Wood, and W. E. Müller, "Lipid membranes and $\beta$-amyloid: a harmful connection," Current Protein and Peptide Science, vol. 11, no. 5, pp. 319-325, 2010.

[62] I. Peters, U. Igbavboa, T. Schütt et al., "The interaction of beta-amyloid protein with cellular membranes stimulates its own production," Biochimica et Biophysica Acta, vol. 1788, no. 5, pp. 964-972, 2009.

[63] S. M. Chafekar, F. Baas, and W. Scheper, "Oligomer-specific A $\beta$ toxicity in cell models is mediated by selective uptake," Biochimica et Biophysica Acta, vol. 1782, no. 9, pp. 523-531, 2008.

[64] M. F. Knauer, B. Soreghan, D. Burdick, J. Kosmoski, and C. G. Glabe, "Intracellular accumulation and resistance to degradation of the Alzheimer amyloid A4/ $\beta$ protein," Proceedings of the National Academy of Sciences of the United States of America, vol. 89, no. 16, pp. 7437-7441, 1992.

[65] L. Saavedra, A. Mohamed, V. Ma, S. Kar, and E. P. De Chaves, "Internalization of $\beta$-amyloid peptide by primary neurons in the absence of apolipoprotein E," Journal of Biological Chemistry, vol. 282, no. 49, pp. 35722-35732, 2007.
[66] T. D. Singh, S.-Y. Park, J.-S. Bae et al., "MEGF10 functions as a receptor for the uptake of amyloid- $\beta$," FEBS Letters, vol. 584, no. 18, pp. 3936-3942, 2010.

[67] B. A. Bahr, K. B. Hoffman, A. J. Yang, U. S. Hess, C. G. Glabe, and G. Lynch, "Amyloid $\beta$ protein is internalized selectively by hippocampal field CA1 and causes neurons to accumulate amyloidogenic carboxyterminal fragments of the amyloid precursor protein," Journal of Comparative Neurology, vol. 397, no. 1, pp. 139-147, 1998.

[68] H. Hering, C. C. Lin, and M. Sheng, "Lipid rafts in the maintenance of synapses, dendritic spines, and surface AMPA receptor stability," Journal of Neuroscience, vol. 23, no. 8, pp. 3262-3271, 2003.

[69] S. Besshoh, D. Bawa, L. Teves, M. C. Wallace, and J. W. Gurd, "Increased phosphorylation and redistribution of NMDA receptors between synaptic lipid rafts and post-synaptic densities following transient global ischemia in the rat brain," Journal of Neurochemistry, vol. 93, no. 1, pp. 186-194, 2005.

[70] X. Bi, C. M. Gall, J. Zhou, and G. Lynch, "Uptake and pathogenic effects of amyloid beta peptide 1-42 are enhanced by integrin antagonists and blocked by NMDA receptor antagonists," Neuroscience, vol. 112, no. 4, pp. 827-840, 2002.

[71] P. N. Lacor, M. C. Buniel, P. W. Furlow et al., "A $\beta$ oligomerinduced aberrations in synapse composition, shape, and density provide a molecular basis for loss of connectivity in Alzheimer's disease," Journal of Neuroscience, vol. 27, no. 4, pp. 796-807, 2007.

[72] E. V. Vassilieva, K. Gerner-Smidt, A. I. Ivanov, and A. Nusrat, "Lipid rafts mediate internalization of $\beta$-integrin in migrating intestinal epithelial cells," American Journal of Physiology, vol. 295, no. 5, pp. G965-G976, 2008.

[73] S. Sabo, M. P. Lambert, K. Kesseya, W. Wade, G. Krafft, and W. L. Klein, "Interaction of beta-amyloid peptides with integrins in a human nerve cell line," Neuroscience Letters, vol. 184, no. 1, pp. 25-28, 1995.

[74] B. A. Bahr, "Integrin-type signaling has a distinct influence on NMDA-induced cytoskeletal disassembly," Journal of Neuroscience Research, vol. 59, no. 6, pp. 827-832, 2000.

[75] P. Chavis and G. Westbrook, "Integrins mediate functional pre- and postsynaptic maturation at a hippocampal synapse," Nature, vol. 411, no. 6835, pp. 317-321, 2001.

[76] G. Juhász, G. Vass, Z. Bozsó, D. Budai, B. Penke, and V. Szegedi, "Integrin activation modulates NMDA and AMPA receptor function of CA1 cells in a dose-related fashion in vivo," Brain Research, vol. 1233, no. 1, pp. 20-26, 2008.

[77] C. S. Chan, E. J. Weeber, L. Zong, E. Fuchs, J. D. Sweatt, and R. L. Davis, " $\beta 1$-integrins are required for hippocampal AMPA receptor-dependent synaptic transmission, synaptic plasticity, and working memory," Journal of Neuroscience, vol. 26, no. 1, pp. 223-232, 2006.

[78] L. A. Cingolani, A. Thalhammer, L. M. Y. Yu et al., "Activity-dependent regulation of synaptic AMPA receptor composition and abundance by beta3 integrins," Neuron, vol. 58, no. 5, pp. 749-762, 2008.

[79] T. Suzuki, J. I. Ito, H. Takagi, F. Saitoh, H. Nawa, and H. Shimizu, "Biochemical evidence for localization of AMPAtype glutamate receptor subunits in the dendritic raft," Molecular Brain Research, vol. 89, no. 1-2, pp. 20-28, 2001.

[80] Q. Hou, Y. Huang, S. Amato, S. H. Snyder, R. L. Huganir, and H. Y. Man, "Regulation of AMPA receptor localization in lipid rafts," Molecular and Cellular Neuroscience, vol. 38, no. 2, pp. 213-223, 2008.

[81] A. A. Cole, A. Dosemeci, and T. S. Reese, "Co-segregation of AMPA receptors with $\mathrm{G}(\mathrm{M} 1)$ ganglioside in synaptosomal 
membrane subfractions," The Biochemical Journal, vol. 427, no. 3, pp. 535-540, 2010.

[82] W. Q. Zhao, F. Santini, R. Breese et al., "Inhibition of calcineurin-mediated endocytosis and $\alpha$-amino-3-hydroxy5-methyl-4-isoxazolepropionic acid (AMPA) receptors prevents amyloid $\beta$ oligomer-induced synaptic disruption," Journal of Biological Chemistry, vol. 285, no. 10, pp. 76197632, 2010.

[83] H. Hsieh, J. Boehm, C. Sato et al., "AMPAR removal underlies Abeta-induced synaptic depression and dendritic spine loss," Neuron, vol. 52, no. 5, pp. 831-843, 2006.

[84] Y. Rui, J. Gu, K. Yu, H. C. Hartzell, and J. Q. Zheng, "Inhibition of AMPA receptor trafficking at hippocampal synapses by -amyloid oligomers: the mitochondrial contribution," Molecular Brain, vol. 3, no. 10, 13 pages, 2010.

[85] K. J. Lee, C. E. H. Moussa, Y. Lee et al., "Beta amyloidindependent role of amyloid precursor protein in generation and maintenance of dendritic spines," Neuroscience, vol. 169, no. 1, pp. 344-356, 2010.

[86] S. Kar, S. P. M. Slowikowski, D. Westaway, and H. T. J. Mount, "Interactions between $\beta$-amyloid and central cholinergic neurons: implications for Alzheimer's disease," Journal of Psychiatry and Neuroscience, vol. 29, no. 6, pp. 427-441, 2004.

[87] H. Y. Wang, D. H. S. Lee, C. B. Davis, and R. P. Shank, "Amyloid peptide $\mathrm{A} \beta$ binds selectively and with picomolar affinity to $\alpha 7$ nicotinic acetylcholine receptors," Journal of Neurochemistry, vol. 75, no. 3, pp. 1155-1161, 2000.

[88] H. Y. Wang, D. H. S. Lee, M. R. D’Andrea, P. A. Peterson, R. P. Shank, and A. B. Reitz, " $\beta$-Amyloid binds to $\alpha 7$ nicotinic acetylcholine receptor with high affinity. Implications for Alzheimer's disease pathology," Journal of Biological Chemistry, vol. 275, no. 8, pp. 5626-5632, 2000.

[89] R. G. Nagele, M. R. D’Andrea, W. J. Anderson, and H. Y. Wang, "Intracellular accumulation of $\beta$-amyloid in neurons is facilitated by the $\alpha 7$ nicotinic acetylcholine receptor in Alzheimer's disease," Neuroscience, vol. 110, no. 2, pp. 199211, 2002.

[90] S. D. Buckingham, A. K. Jones, L. A. Brown, and D. B. Sattelle, "Nicotinic acetylcholine receptor signalling: Roles in alzheimer's disease and amyloid neuroprotection," Pharmacological Reviews, vol. 61, no. 1, pp. 39-61, 2009.

[91] G. M. Khan, M. Tong, M. Jhun, K. Arora, and R. A. Nichols, " $\beta$-Amyloid activates presynaptic $\alpha 7$ nicotinic acetylcholine receptors reconstituted into a model nerve cell system: involvement of lipid rafts," European Journal of Neuroscience, vol. 31, no. 5, pp. 788-796, 2010.

[92] C. M. Hernandez, R. Kayed, H. Zheng, J. D. Sweatt, and K. T. Dineley, "Loss of $\alpha 7$ nicotinic receptors enhances $\beta$-amyloid oligomer accumulation, exacerbating early-stage cognitive decline and septohippocampal pathology in a mouse model of Alzheimer's disease," Journal of Neuroscience, vol. 30, no. 7, pp. 2442-2453, 2010.

[93] G. Dziewczapolski, C. M. Glogowski, E. Masliah, and S. F. Heinemann, "Deletion of the $\alpha 7$ nicotinic acetylcholine receptor gene improves cognitive deficits and synaptic pathology in a mouse model of Alzheimer's disease," Journal of Neuroscience, vol. 29, no. 27, pp. 8805-8815, 2009.

[94] J. Kim, J. M. Basak, and D. M. Holtzman, "The role of apolipoprotein E in Alzheimer's disease," Neuron, vol. 63, no. 3, pp. 287-303, 2009.

[95] K. R. Bales, T. Verina, D. J. Cummins et al., "Apolipoprotein $\mathrm{E}$ is essential for amyloid deposition in the APP(V717F) transgenic mouse model of Alzheimer's disease," Proceedings of the National Academy of Sciences of the United States of America, vol. 96, no. 26, pp. 15233-15238, 1999.

[96] D. B. Carter, "The interaction of amyloid-beta with ApoE," Sub-Cellular Biochemistry, vol. 38, pp. 255-272, 2005.

[97] S. Aleshkov, C. R. Abraham, and V. I. Zannis, "Interaction of nascent apoe2, apoe3, and apoe4 isoforms expressed in mammalian cells with amyloid peptide $\beta$ (1-40). Relevance to Alzheimer's disease," Biochemistry, vol. 36, no. 34, pp. 1057110580, 1997.

[98] K. H. Gylys, J. A. Fein, A. M. Tan, and G. M. Cole, "Apolipoprotein E enhances uptake of soluble but not aggregated amyloid- $\beta$ protein into synaptic terminals," Journal of Neurochemistry, vol. 84, no. 6, pp. 1442-1451, 2003.

[99] I. Dafnis, E. Stratikos, A. Tzinia, E. C. Tsilibary, V. I. Zannis, and A. Chroni, "An apolipoprotein E4 fragment can promote intracellular accumulation of amyloid peptide beta 42," Journal of Neurochemistry, vol. 115, no. 4, pp. 873-884, 2010.

[100] F. M. LaFerla, J. C. Troncoso, D. K. Strickland, C. H. Kawas, and G. Jay, "Neuronal cell death in Alzheimer's disease correlates with apoE uptake and intracellular $\mathrm{A} \beta$ stabilization," Journal of Clinical Investigation, vol. 100, no. 2, pp. 310-320, 1997.

[101] G. Bu, J. Cam, and C. Zerbinatti, "LRP in amyloid- $\beta$ production and metabolism," Annals of the New York Academy of Sciences, vol. 1086, pp. 35-53, 2006.

[102] R. A. Fuentealba, Q. Liu, J. Zhang et al., "Low-density lipoprotein receptor-related protein 1 (LRP1) mediates neuronal A $\beta 42$ uptake and lysosomal trafficking," PLoS One, vol. 5, no. 7, Article ID e11884, 2010.

[103] C. V. Zerbinatti, S. E. Wahrle, H. Kim et al., "Apolipoprotein $\mathrm{E}$ and low density lipoprotein receptor-related protein facilitate intraneuronal A $\beta 42$ accumulation in amyloid model mice," Journal of Biological Chemistry, vol. 281, no. 47, pp. 36180-36186, 2006.

[104] K. Yamada, T. Hashimoto, C. Yabuki et al., "The low density lipoprotein receptor-related protein 1 mediates uptake of amyloid $\beta$ peptides in an in vitro model of the blood-brain barrier cells," Journal of Biological Chemistry, vol. 283, no. 50, pp. 34554-34562, 2008

[105] L. Wu and S. L. Gonias, "The low-density lipoprotein receptor-related protein-1 associates transiently with lipid rafts," Journal of Cellular Biochemistry, vol. 96, no. 5, pp. 1021-1033, 2005.

[106] T. Kanekiyo and G. Bu, "Receptor-associated protein interacts with amyloid- $\beta$ peptide and promotes its cellular uptake," Journal of Biological Chemistry, vol. 284, no. 48, pp. 33352-33359, 2009.

[107] K. Takuma, F. Fang, W. Zhang et al., "RAGE-mediated signaling contributes to intraneuronal transport of amyloid$\beta$ and neuronal dysfunction," Proceedings of the National Academy of Sciences of the United States of America, vol. 106, no. 47, pp. 20021-20026, 2009.

[108] R. Giri, Y. Shen, M. Stins et al., " $\beta$-amyloid-induced migration of monocytes across human brain endothelial cells involves RAGE and PECAM-1," American Journal of Physiology, vol. 279, no. 6, pp. C1772-C1781, 2000.

[109] O. Arancio, H. P. Zhang, X. Chen et al., "RAGE potentiates $\mathrm{A} \beta$-induced perturbation of neuronal function in transgenic mice,” EMBO Journal, vol. 23, no. 20, pp. 4096-4105, 2004.

[110] J. X. Chen and S. D. Yan, "Pathogenic role of mitochondrial [correction of mitochondral] amyloid-beta peptide," Expert Review of Neurotherapeutics, vol. 7, no. 11, pp. 1517-1525, 2007. 
[111] T. Hayashi, R. Rizzuto, G. Hajnoczky, and T. P. Su, "MAM: more than just a housekeeper," Trends in Cell Biology, vol. 19, no. 2, pp. 81-88, 2009.

[112] C. A. Hansson Petersen, N. Alikhani, H. Behbahani et al., "The amyloid $\beta$-peptide is imported into mitochondria via the TOM import machinery and localized to mitochondrial cristae," Proceedings of the National Academy of Sciences of the United States of America, vol. 105, no. 35, pp. 13145-13150, 2008.

[113] K. Boland, K. Manias, and D. H. Perlmutter, "Specificity in recognition of amyloid- $\beta$ peptide by the serpin-enzyme complex receptor in hepatoma cells and neuronal cells," Journal of Biological Chemistry, vol. 270, no. 47, pp. 28022 28028, 1995.

[114] S. Kumari, S. Mg, and S. Mayor, "Endocytosis unplugged: multiple ways to enter the cell," Cell Research, vol. 20, no. 3, pp. 256-275, 2010.

[115] P. Lajoie and I. R. Nabi, "Regulation of raft-dependent endocytosis," Journal of Cellular and Molecular Medicine, vol. 11, no. 4, pp. 644-653, 2007.

[116] R. Rollason, V. Korolchuk, C. Hamilton, P. Schu, and G. Banting, "Clathrin-mediated endocytosis of a lipid-raftassociated protein is mediated through a dual tyrosine motif," Journal of Cell Science, vol. 120, no. 21, pp. 3850-3858, 2007.

[117] N. Masuyama, T. Kuronita, R. Tanaka et al., "HM1.24 is internalized from lipid rafts by Clathrin-mediated endocytosis through interaction with $\alpha$-adaptin," Journal of Biological Chemistry, vol. 284, no. 23, pp. 15927-15941, 2009.

[118] R. C. Carroll, E. C. Beattie, H. Xia et al., "Dynamindependent endocytosis of ionotropic glutamate receptors," Proceedings of the National Academy of Sciences of the United States of America, vol. 96, no. 24, pp. 14112-14117, 1999.

[119] S. Kumari, V. Borroni, A. Chaudhry et al., "Nicotinic acetylcholine receptor is internalized via a Rac-dependent, dynamin-independent endocytic pathway," Journal of Cell Biology, vol. 181, no. 7, pp. 1179-1193, 2008.

[120] C. Yu, E. Nwabuisi-Heath, K. Laxton, and M. J. Ladu, "Endocytic pathways mediating oligomeric A $\beta 42$ neurotoxicity," Molecular Neurodegeneration, vol. 5, no. 1, article 19, 2010.

[121] K. K. Kandimalla, O. G. Scott, S. Fulzele, M. W. Davidson, and J. F. Poduslo, "Mechanism of neuronal versus endothelial cell uptake of Alzheimer's disease amyloid beta protein," PLoS One, vol. 4, no. 2, p. e4627, 2009.

[122] R. P. Mason, R. F. Jacob, M. F. Walter et al., "Distribution and fluidizing action of soluble and aggregated amyloid $\beta$-peptide in rat synaptic plasma membranes," Journal of Biological Chemistry, vol. 274, no. 26, pp. 18801-18807, 1999. 


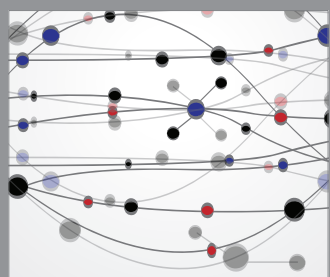

The Scientific World Journal
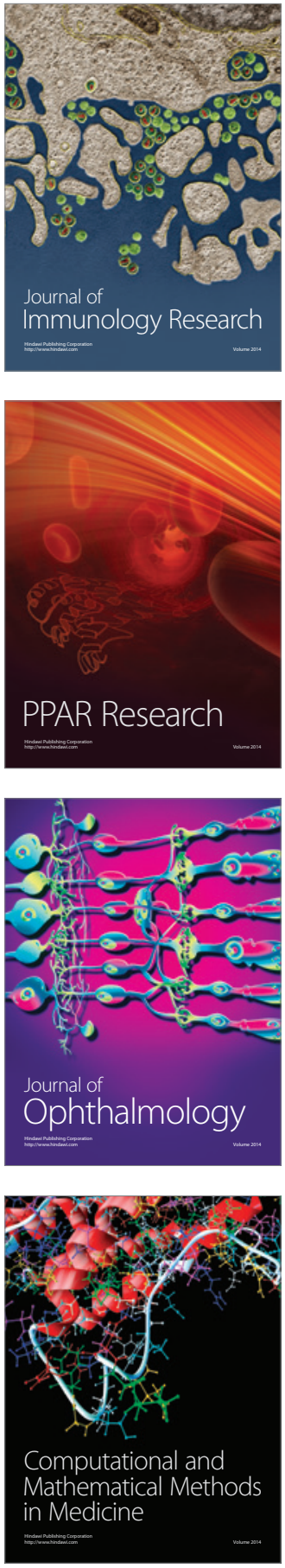

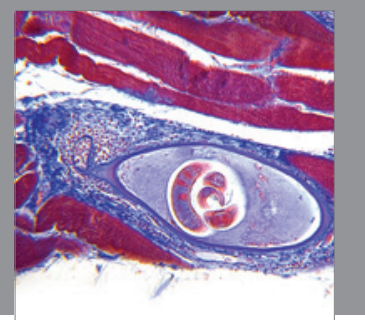

Gastroenterology

Research and Practice
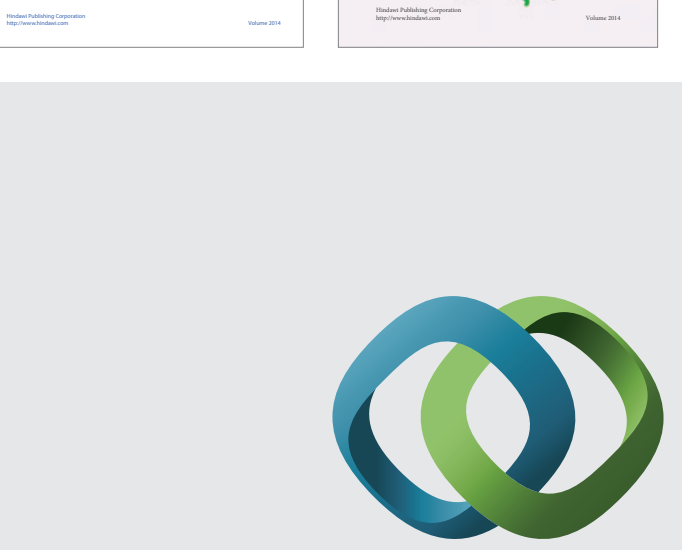

\section{Hindawi}

Submit your manuscripts at

http://www.hindawi.com
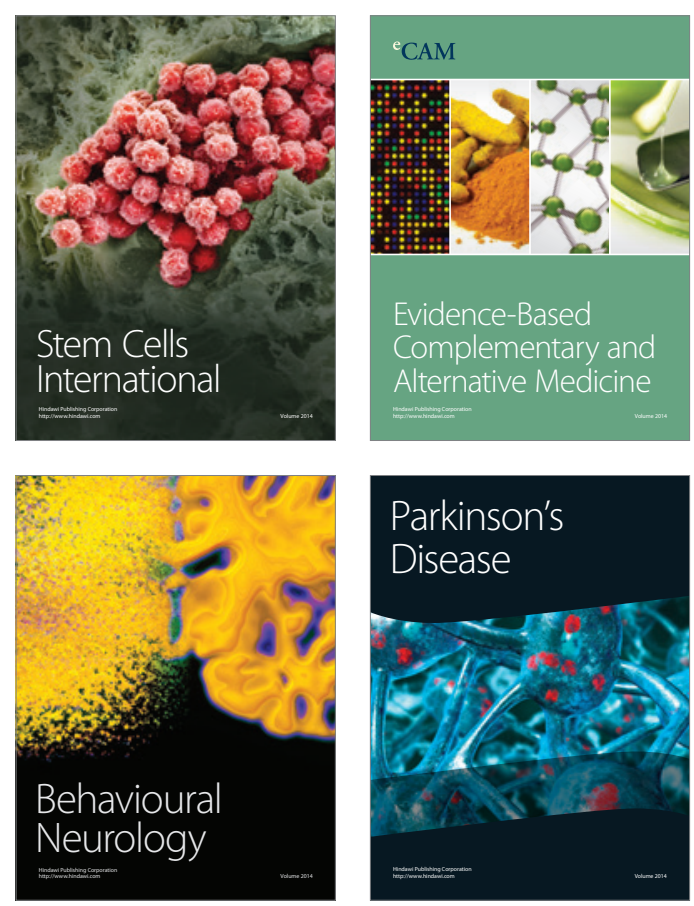

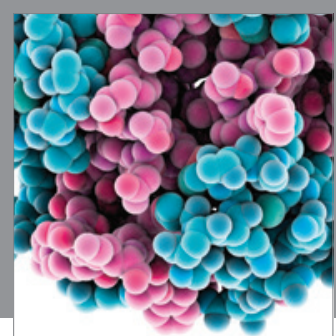

Journal of
Diabetes Research

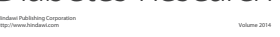

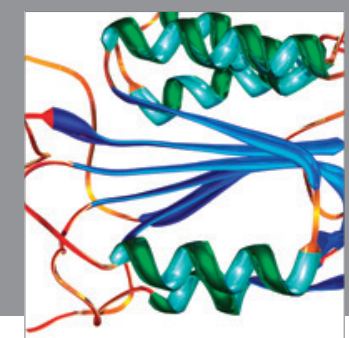

Disease Markers
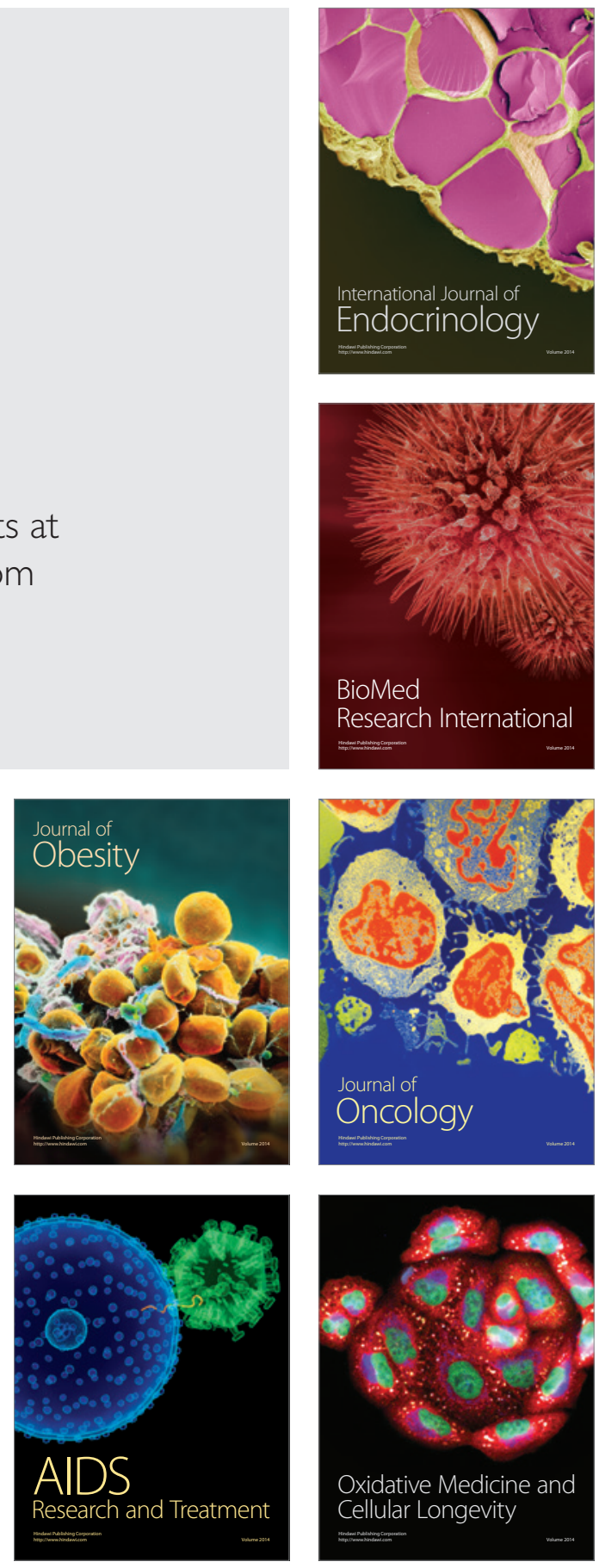